\title{
Rare Campanian Echinoids from Höver and Misburg (Hannover Area, Lower Saxony, Germany)
}

\author{
Christian Neumann ${ }^{1}$, John W. M. Jagt ${ }^{2} \&$ Raymond W. J. M. van der Ham ${ }^{3}$
}

With 3 figures and 3 plates

\begin{abstract}
Amongst the rich and fairly diverse echinoid faunas from the Campanian marl/marly limestone facies as exposed at the large quarries of the cement industry near Höver and Misburg (east of Hannover, northern Germany), there are a few rare taxa, most of which have not been recorded previously from the Lower Saxony Basin. These include Echinogalerus peltiformis (Wahlenberg, 1821), Conulus (C.) matesovi Poslavskaia \& Moskvin in Moskvin 1959, Hagenowia blackmorei Wright \& Wright, 1949, Diplodetus sp., and Peroniaster cotteaui Gauthier in Peron 1887. New material of another rare species, Hemiaster gr. aquisgranensis Schlüter, 1899, is here described. The palaeoecological significance of the rarity of these is briefly discussed. Of particular note, in a palaeobiogeographic context, are E. peltiformis and C. matesovi. The former is well known from Lower and Upper Campanian arenitic facies in southern Sweden, while the latter was held to be confined to the Lower Campanian of the Caucasus and Kazakhstan. These two species may have immigrated into the Lower Saxony Basin following transgressive pulses or within transgressive systems tracts.
\end{abstract}

Key words: Echinoidea, Campanian, Höver, Misburg, new records, palaeoecology, palaeobiogeography, immigration.

\section{Zusammenfassung}

Die reiche und vergleichsweise diverse Echinidenfauna der Mergel/Mergelkalk-Rhythmite des Campans von Misburg und Höver bei Hannover enthält einige seltene Taxa, die bisher aus dem Niedersächsischen Becken nicht bekannt waren. Dazu gehören Echinogalerus peltiformis (Wahlenberg, 1821), Conulus (C.) matesovi Poslavskaia \& Moskvin in Moskvin 1959, Hagenowia blackmorei Wright \& Wright, 1949, Diplodetus sp. und Peroniaster cotteaui Gauthier in Peron 1887. Für eine weitere Art, Hemiaster gr. aquisgranensis Schlüter, 1899, werden neue Funde beschrieben. Die paläoökologische Bedeutung der Seltenheit der vorliegenden Taxa wird diskutiert. Als besonders bedeutsam erweisen sich dabei die Vorkommen von $E$. peltiformis und $C$. matesovi. Ersterer war bisher ausschließlich aus den küstennahen Kalkareniten Südschwedens bekannt, letzterer wurde bisher nur im Untercampan des Kaukasus und von Asserbaidschan und Kasachstan nachgewiesen. Beide Arten sind wahrscheinlich im Rahmen transgressiver Schübe dritter Ordnung in das Niedersächsische Becken eingewandert.

Schlüsselwörter: Echinoidea, Campan, Höver, Misburg, Erstnachweise, Paläoökologie, Paläobiogeographie, Faunen-Migrationen.

\section{Introduction}

In the Lehrte West syncline (central Lower Saxony Basin), an undisturbed succession of marls and marly limestones of Campanian age is well exposed in several large quarries of the cement industry (Fig. 1, and compare Khosrovshahian [1972], Ernst [1975], Ernst et al. [1979, 1997a-c], and Volkmann [1998]). In particular, the "Alemannia" (Höver) and "Teutonia" (Misburg) quarries, east of Hannover, are famous for their well-preserved and fairly diverse echinoid faunas. More than twenty taxa within the cohort Irregularia are now known (see Appendix 1). Extensive study of museum and private collections as well as new finds have led to the recognition of five echinoid taxa not previously recorded from the area. Of the sixth rare species, Hemiaster gr. aquisgranensis, recently collected material is here described and illustrated.

\footnotetext{
${ }^{1}$ Institut für Paläontologie, Museum für Naturkunde der Humboldt Universität, Invalidenstraße 43, D-10115 Berlin, Germany.

E-mail: christian.neumann@museum.hu-berlin.de

2 Natuurhistorisch Museum Maastricht, P.O. Box 882, NL-6200 AW Maastricht, the Netherlands.

E-mail: john.jagt@maastricht.nl

${ }^{3}$ Piet Heinstraat 6, NL-2628 RK Delft, the Netherlands. E-mail: Ham@nhn.leidenuniv.nl

Received February 2002, accepted June 2002
} 


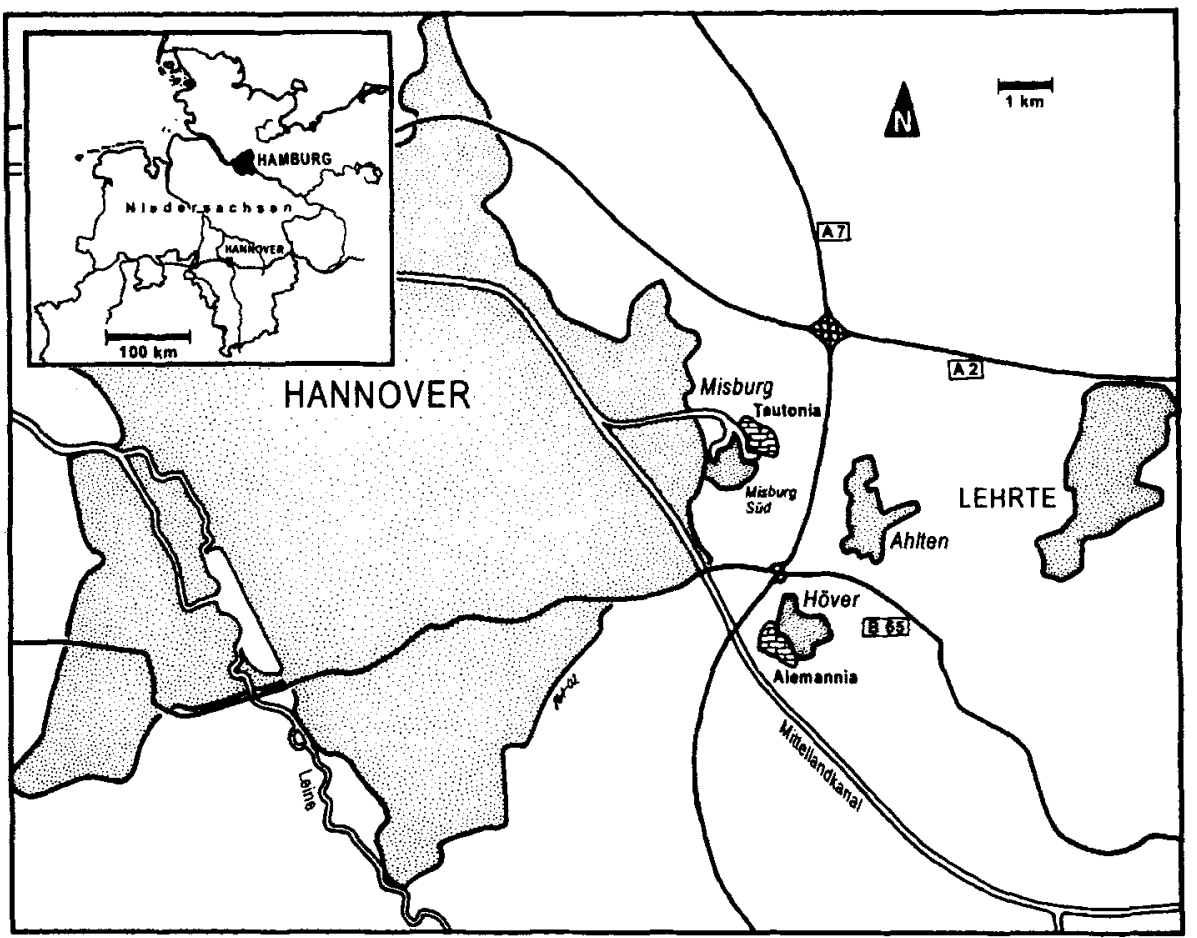

Fig. 1. Map of the Hannover area showing the location of the Teutonia (Misburg) and Alemannia (Höver) quarries.
Campanian echinoid faunas of the Hannover area have been the subject of numerous studies during more than thirty years, and these studies focused either on palaeoecological aspects (Ernst 1970a), particular echinoid lineages (Ernst 1970b, 1971, 1972, Ernst et al. 1971, Frerichs 1989) or their biostratigraphical potential (Ernst 1970c, Ernst \& Seibertz 1977, Schulz 1985). The aim of the present paper is to document differences between rare and common taxa and to attempt to reconstruct the various processes behind them. In recent years, the signals in macrofossil groups within sequence-stratigraphic schemes have received some attention (Ernst \& Wood 1996). Amongst echinoids, immigration of certain species into the area may be linked directly to transgressive surfaces or transgressive systems tracts. At least one of the rare echinoid species discussed in the present paper (C. matesovi) testifies to such events across northern and eastern Europe, as far southeast as the Caucasus.

\section{Institutional Abbreviations}

To denote the repositories of material referred to in the text the following abbreviations are used:

BGR Bundesanstalt für Geowissenschaften und Rohstoffe, Hannover;

MB.E Museum für Naturkunde, Humboldt Universität Berlin;

NHMM Natuurhistorisch Museum Maastricht, Maastricht; and

RFWUIP Rheinische Friedrich-Wilhelms-Universität, Institut für Paläontologie, Bonn (C. Schlüter Colln).

\section{Systematic palaeontology}

Or de r Echinoneoida H.L. Clark, 1925

Fa mily Conulidae Lambert, 1911

Genus and subgenus Conulus (Conulus) Leske, 1778

Type species: Conulus albogalerus Leske 1778, by monotypy.

Plate 1. Conulus matesovi and Conulus haugi. 1-4. Conulus (Conulus) matesovi Poslavskaia \& Moskvin in Moskvin, 1959 , MB.E 3593 in four aspects (1. posterior; 2. lateral; 3. aboral; 4. oral). Alemannia quarry (Höver), upper papillosaflower conical papillosa Zone interval (Lower Campanian). 5-8. Conulus (Conulus) matesovi Poslavskaia \& Moskvin in Moskvin, 1959, MB.E 3592 in various aspects (5. posterior; 6. lateral; 7. aboral; 8. oral); Alemannia quarry (Höver), gracilis/mucronata Zone (upper Lower Campanian). 9-10. Conulus haugi Lambert, 1935, MB.E 3597 (cast; original in W. Judenhagen Colln) in various aspects (9. oral; 10. lateral); from temporary motorway outcrop at Sarasate (Barranca, northeast Spain), Lower Campanian. 11-12. Conulus (Conulus) matesovi Poslavskaia \& Moskvin in Moskvin 1959, MB.E 3594 in two aspects (11. lateral; 12. oral); Heidestrasse quarry (Lägerdorf); gracilis/mucronata Zone, level F62-1.15 m (upper Lower Campanian; see Schulz \& Weitschat 1998). Scale bar for all figures equals $10 \mathrm{~mm}$. 


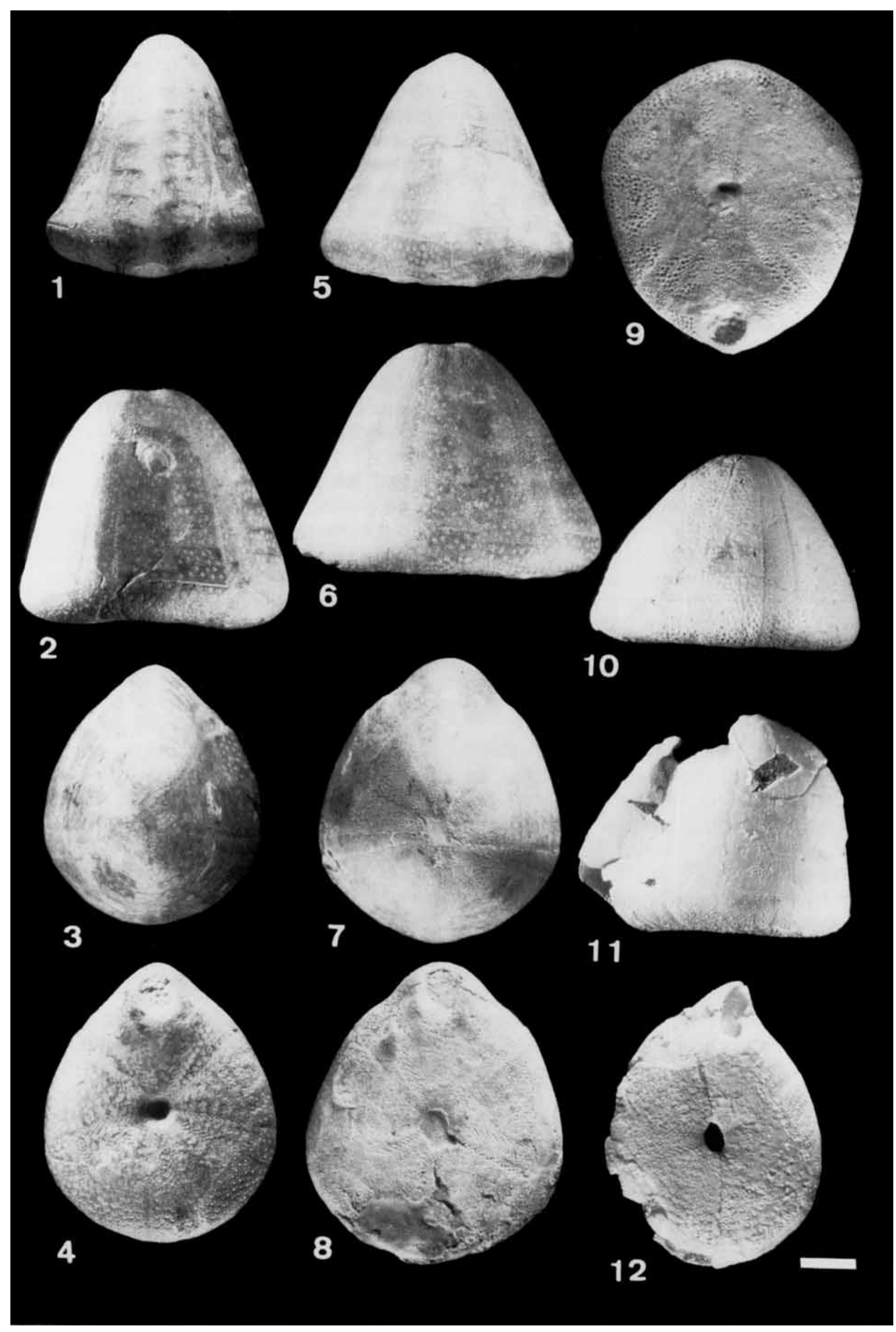




\section{Conulus (Conulus) matesovi Poslavskaia \& Moskvin in Moskvin, 1959}

Pl. 1: 1-8 and 11-12

*1959 Conulus matesovi - Poslavskaia \& Moskvin in Moskvin, p. 251, pl. 3, fig. 2 .

?1988 Conulus matesovae [sic] Moskvin - Ali-Zade et al., p. 188 , pl. 2, fig. 1; text-fig. 7 .

Material: Two fairly well-preserved specimens (MB.E 3592 and 3593), from the upper papillosal lower conica/gracilis Zone interval and gracilis/ mucronata Zone, respectively, at Höver (Alemannia), and a single fragmentary, poorly preserved specimen (MB.E 3594, ex M.-G. Schulz Colln) from the Upper Campanian (gracilis/mucronata Zone) at Lägerdorf (quarry 'Heidestrasse').

Measurements (in $\mathrm{mm}$ ):

\begin{tabular}{lrrll}
\hline & 1 & 2 & 3 & \multicolumn{1}{l}{4} \\
\hline Width & 41.4 & 49.9 & $36.4^{*}$ & 40.0 \\
Length & 49.0 & 58.2 & $46.6^{*}$ & 45.0 \\
Height & 43.1 & 43.0 & $37.3^{*}$ & 40.0 \\
L peristome & 5.9 & 6.0 & - & - \\
W periproct & 6.6 & 6.9 & - & - \\
\hline
\end{tabular}

$1=$ MB.E 3592 (ex J. van den Essen Colln)

$2=$ MB.E 3593 (cast; original in D. Licht Colln)

$3=$ MB.E 3594 (ex M.-G. Schulz Colln)

4 = holotype of $C$. matesovi (see Poslavskaia \& Moskvin in Moskvin 1959, p. 251).

* = approximate

Description: Both specimens from Höver have suffered slightly from compaction and are abraded in places; in addition, the larger one shows partial recrystallisation, in particular apically. Both are distinctly longer than wide (L/W ratio 1.2 and 1.2 vs 1.1 in the holotype), their outline being subcircular to subpentagonal, with the posterior end more or less constricted. In profile, both specimens are tall with straight anterior/posterior and slightly concave lateral flanks, and have anterior and posterior elevations bordering the apical disc. Test height corresponds to 88 and $74 \%$ of test length, respectively (vs $89 \%$ in the holotype). The ambitus is situated very low on the test, around $10 \%$ of test height above the base. The oral surface forms a flat to slightly concave and broad base, with the posterior interambulacrum slightly elevated around the periproct. As preserved in MB.E 3592 (Pl. 1: 1-4), the apical disc has an enlarged genital plate 2 which does not contact the posterior ocular plates and separate the posterior two genital plates. Ambulacra are comparatively narrow (width ratio A/IA directly above ambitus 0.3 and 0.3 ), with simple, undifferentiated oblique pore pairs adapically; pyrinoid plating developing at mid-flank and continuing adorally, occurring in oblique triads on the oral surface. Adapically, every second or third plate with single perforate tubercle close to pore pair, in centre of ring-shaped depression. Interambulacra wide with scattered tubercles of comparable size, as well as much smaller bead-like secondary spines and granules. The peristome is subcentral, subcircular to slightly elongate along axis 3-I. The periproct is oval, widest in posterior half, corresponding to 14.1 and $11.9 \%$ of test length, respectively. Periproct position inframarginal, nearly oral on account of low position of ambitus, just partially visible in posterior profile.

Although fragmentary and much more poorly preserved, MB.E 3594 (Pl. 1: 11-12) from Lägerdorf corresponds in all details of ambulacral plating and tuberculation. It is laterally compressed, which accounts for the fact that test measurements (length, width, height) cannot be but approximate. Moreover, it is impossible to measure peristome length and periproct width. Although having less concave lateral flanks, this test is otherwise closely comparable to the specimens from Höver and is here considered to be conspecific.

Discussion: The closest resemblance of the present specimens is to Conulus matesovi, originally recorded from the Lower Campanian of the Caucasus (Poslavskaia \& Moskvin in Moskvin 1959). Subsequently, Moskvin \& Endel'man (1972: 7, table) showed it to range from the upper Lower into possibly lower Upper Campanian of Mangyshlak. Identification of MB.E 3592 from Höver and of MB.E 3594 from Lägerdorf as $C$. matesovi was favoured by the late M.-G. Schulz (pers. comm., July 1985); we concur.

As pointed out by Smith \& Wright (1999: 374), species of Conulus have been distinguished previously almost exclusively on test shape and lateral profile. Although characteristic shapes occur at different stratigraphic levels, it appears that there are no clear-cut differences as far as plating, tuberculation and ambulacral structure are concerned. Smith \& Wright (1999) accepted as valid: C. castanea (Brongniart, 1822) (p. 336, pl. 9, fig. 14), ranging from the mid-Albian to the early Late Cenomanian, C. subrotundus Mantell, 1822 (p. 191, pl. 17, figs 15, 18), from the Turonian-Santonian and C. albogalerus Leske, 1778 (p. 162, pl. 13a, b), which ranges from the Late Coniacian to Early Campanian, but which is best known from the Santonian (see also Malinowska 
1989). Interestingly, Smith \& Wright (1999) synonymised $C$. matesovi with $C$. albogalerus, noting that specimens referred to the latter species occurred in the Lower Campanian of Rottingdean (Sussex) and Winchester (Hampshire), England. However, these authors remarked (p. 382) that in $C$. albogalerus tests were slightly wider than long, subcircular to subpentagonal in outline, with width $87-98 \%$ of length (mean $92 \%$ ), and had a tall domal to conical profile, with height $65-100 \%$ of test length (mean $82 \%$ ), as well as an oval periproct, $10-13 \%$ of test length.

Although test height/length and periproct width/length ratios of the present specimens and of C. albogalerus (sensu Smith \& Wright 1999) overlap, the German material is distinctly longer than wide, has concave lateral flanks, a more or less constricted posterior test surface (around periproct), is flattened apically (highest points just anterior and posterior of apical disc), and has a more longitudinal periproct. Although some specimens of C. albogalerus (e.g., pl. 123, figs 1-4, Santonian of Kent, England, in Smith \& Wright 1999) are more or less comparable in profile, their ambulacra appear to be wider and their lateral flanks are not concave. Remarkable is, that the holotype of $C$. matesovi and both specimens from Höver (in the Lägerdorf specimen this is much less clearly marked) have concave lateral flanks, and suggests that this may be a feature typical of that species. This assumption becomes even more convincing when another species, Conulus campaniformis Melikov \& Endel'man, 1963 (p. 136, fig. 1), from the Lower Maastrichtian of the Caucasus, is considered. This has even more concave flanks, is of comparable size to $C$. matesovi (length/width ratios $1.04-1.10$; test height $76.5-89.3 \%$ of test length), and appears to be a direct descendant of that species. The 'lineage' is characterised by an increase in lateral flank concavity, and may be an offshoot of the main albogalerus lineage, more or less confined to the Campanian-Maastrichtian of the southeastern part of the Russian Platform, with the exception of the present records. In order to test this hypothesis more material is needed from the type areas of both forms. For the time being, we here consider the taxa to be distinct species that may be differentiated from congeners (see below) on test profile mainly; ambulacral structure and width is another feature that warrants closer inspection.

The specimen of $C$. matesovae [sic] illustrated by Ali-Zade et al. (1988: pl. 2a, fig. 1) differs from the material described here in lacking the concave lateral flanks and in having less regular ambulacral plating; it may be more closely related to specimens referred to $C$. albogalerus from the Lower Campanian of England by Smith \& Wright (1999).

Other European Campanian-Maastrichtian species of Conulus, recorded in the literature (Radig 1973; Kutscher 1986; Jeffery 1997; Smith et al. 1999; Smith \& Jeffery 2000) are:

Conulus douvillei (Cotteau \& Gauthier, 1895: 70, pl. 11, figs 9-13) (see Smith \& Jeffery 2000: 144 , fig. $60 \mathrm{~g}-\mathrm{k}$ ), from the Campanian of Saudi Arabia and the Maastrichtian of Libya, Oman/ United Arab Emirates border regions, Baluchistan, India and Tibet. This clearly differs from C. matesovi in having a large, strongly oblique peristome, a submarginal periproct; in addition, test width is between 80 and $95 \%$ of test length.

Conulus gigas (Cotteau in Leymerie \& Cotteau 1856: 330) (see Smith \& Jeffery 2000, fig. $60 \mathrm{a}, \mathrm{b}$ ) from the Maastrichtian of France and northern Spain (see Wilmsen et al. 1996), Libya and Cuba, differs from $C$. matesovi in having an inflated test with rounded margins, a tumid oral surface with a slightly sunken, relatively small peristome as well as a submarginal periproct.

Conulus magnificus (d'Orbigny, 1854: 540, pl. 1004), a late Early to Late Maastrichtian species from Mangyshlak (Kazakhstan), Crimea, northern Caucasus, Bulgaria, ?Kopet Dag, ?Azerbaijan, northern Germany and Denmark, differs from $C$. matesovi in having a transversely oval periproct, fine aboral tuberculation and aboral pore pairs that are strongly oblique and well separated.

Conulus? placentula (Stoliczka, 1873: 36, pl. 6, fig. 4), from the Campanian-Maastrichtian of India (see Smith \& Jeffery 2000: 146, fig. 60e, f) is easily distinguished by its depressed profile, a small peristome and a submarginal, longitudinally oval periproct.

Moskvin et al. (1980) listed a few other 'species' from the Maastrichtian of the Caucasus and Mangyshlak, but as Smith \& Jeffery (2000: 147) have recently pointed out, these cannot be properly compared due to lack of illustrations and/or descriptions.

Gallemí et al. (1995: 268, table 1) recorded Conulus haugi Lambert 1935 from the Upper Campanian (Unit 3) of the Internal Prebetic (southeast Spain), also known from Navarra and the Pyrenees. According to these authors, Conulus mattesovae [sic], from the Caucasus and Mangyshlak, is a synonym of $C$. haugi. We do not 
subscribe to this view, pending a revision of $C$. haugi. A single specimen (MB.E 3597), of Campanian age, from a temporary motorway outcrop at Sarasate (Barranca, northeast Spain; Pl. 1: 9-10), which may be assigned to $C$. haugi (? = Conulus sp. of Küchler 2000: 453, fig. 4) has a less elongate periproct, a comparatively smaller peristome, lacks the concave lateral flanks of $C$. matesovi, and the ambital $\mathrm{A} / \mathrm{IA}$ ratio differs, with more regular plating. In addition, the $\mathrm{L} / \mathrm{W}$ ratio is 1.1 , and test height corresponds to $70.1 \%$ of test length.

Occurrence: Campanian of the Caucasus region, Kazakhstan and Germany.

Orde r Cassiduloida Claus, 1880

Family Pygaulidae Lambert, 1905

Genus Echinogalerus König, 1825

Type species: Echinites peltiformis Wahlenberg, 1821, by subsequent designation of Lambert (1898).

\section{Echinogalerus peltiformis (Wahlenberg, 1821)}

Pl. 2: 1-3

*1821 Echinites peltiformis - Wahlenberg, p. 50, pl. 3, fig. 1 .

1976 Echinogalerus peltiformis (Wahlenberg) - Reyment, p. 5 , fig. 15

1995 Echinogalerus sp. - Frerichs, p. 14, fig. 10 (partim).

Material: A single specimen (MB.E 3595 cast; original in U. Frerichs Colln, Hannover, number F1) from the upper Lower Campanian (senonensis or papillosa- Zone) of the Alemannia quarry (Höver). The tests in the I. Krause Colln, Hannover (numbers K1, K2; see Frerichs 1995: fig. 11) have not been restudied, but may be conspecific.

Description: Medium-sized test (length $18.2 \mathrm{~mm}$, width $16.1 \mathrm{~mm}$, height $12.3 \mathrm{~mm}$ ), outline elliptical, greatest test width at mid-length; profile rather high. Oral side pulvinate, apical side domed; apex slightly anterior to mid-length. Ambulacra nonpetaloid, with double pores aborally; pore pairs small, each in a shallow pit. Peristome oblique, periproct inframarginal, $4 \mathrm{~mm}$ wide, transversely elliptical to triangular. Tubercles relatively small but distinct, also above periproct, slightly more pronounced anteriorly.

Discussion: Van der Ham \& van Birgelen (2002) tentatively distinguish three infrageneric 'groupings', as well as a number of more or less isolated species within the genus Echinogalerus. 'Group 1' includes species with an elliptical outline, subpetaloid ambulacra with distinct double pores aborally, an oblique peristome and a relatively large periproct, viz. Echinogalerus faba (Desor, 1842) from the Cenomanian of western France and south-west England, E. goslariensis (Schlüter, 1902) [Santonian of northern Germany], E. muelleri (Schlüter, 1902) [Maastrichtian of the southeast Netherlands and northern Spain], and E. rutoti (Lambert, 1898) [Maastrichtian of southern Belgium].

'Group 2' comprises species with an elliptical outline, nonpetaloid ambulacra with small pore pairs in shallow pits, an oblique peristome and a relatively large periproct, viz. Echinogalerus bueltenensis (Schlüter, 1902) (Santonian of northern Germany) and E. peltiformis (Campanian of southern Sweden).

'Group 3' includes species with a circular outline, nonpetaloid ambulacra with small pore pairs in shallow pits, a near-circular peristome and a relatively small, vaguely triangular to circular periproct, viz. Echinogalerus circularis (Schlüter, 1902) [Turonian of north-west Germany], E. tenuiporus (Schlüter, 1902) [Maastrichtian of northern Germany], E. vetschauensis (Schlüter, 1902) [Maastrichtian of the southeast Netherlands and northern Spain], and possibly also $E$. dolfussi (Lambert 1898) and E. truncatus (d'Orbigny, 1857) [both Maastrichtian of western France].

Other species of Echinogalerus are difficult to tie in with the above groupings. Echinogalerus belgicus (Lambert, 1898) and E. pusillus Lambert, 1911 both from theMaastrichtian of the southeast Netherlands have simple pores, while E. minutus (Smiser, 1935) [Maastrichtian of the southeast Netherlands] resembles E. gehrdensis (Roemer, 1841) [Santonian of north-west Germany] in having a concave oral side and a symmetrical peristome. Echinogalerus rostratus (Desor, 1842) [Cenomanian of western France and south-west England] is similar to these two species, but has a flat oral side, whereas $E$. althi (Zarczny, 1878) [?Turonian of Poland], E. laubei (Novák, 1887) [Turonian of Bohemia], and E. orbicularis (Desor, 1842) [Cenomanian of western France] are poorly known.

Based on these observations, the species of Echinogalerus from Höver discussed here, belongs to the bueltenensis-peltiformis group ('Group 2'). These two species are morphologically closely related (see Ernst 1973). Echinogalerus bueltenensis is well known from the Middle Santonian of the Hannover area; specimens from 
Lengede (H.-V. Thiel Colln), Hoheneggelsen and Groß-Bülten (G. Ernst Colln; see Fig. 2B) studied for the present paper closely match Schlüter's (1902) description and illustrations. Echinogalerus peltiformis from the Lower Campanian of Skane has been illustrated by Wahlenberg (1821), d'Orbigny (1857), Lambert (1911), Reyment (1976) and Zuidema (1999). The type specimen is present in the Palaeontological Institute in Uppsala (comm. W. Kegel Christensen), but has not been studied. Instead, we have compared the specimen from Höver with other material from southern Sweden, all labelled E. peltiformis (see Fig. 2C) and contained in the Swedish Museum of Natural History in Stockholm. According to Schlüter (1902: 308), E. peltiformis may reach overall test lengths of $25 \mathrm{~mm}$.

Echinogalerus bueltenensis and E. peltiformis are closely similar. The only difference detected so far is the position of the apex, which is clearly anterior to mid-length in the former, and at midlength or just slightly anterior to it in the latter. On the basis of this character, the Höver specimen is here assigned to E. peltiformis; thus extending the geographical distribution of this taxon from southern Sweden to northeast Germany.

To round off this section, a few words on the co-occurring Echinoconus hannoniensis Lambert, 1911, are needed. This species was referred to as Echinogalerus (?) hannoniensis by Schulz (1985) and is known from the upper Lower Campanian of the Hannover area (e.g., Höver). Schulz (1985) discussed its possible assignment to the genus Echinogalerus. Based on the original description and illustrations (Roemer 1841, as $G a$ lerites globosus), this species has a much more spherical test than E. peltiformis from Höver: its width and height are $93 \%$ and $87 \%$ of test length respectively (vs. $88 \%$ and $68 \%$ in $E$ peltiformis). Schulz (1985) indicated a range between 11.3 and $15.2 \mathrm{~mm}$ for eight specimens from Höver, while Ernst (1972) noted lengths between 6 and $16 \mathrm{~mm}$ for 58 specimens from Oberg near Peine. Echinogalerus peltiformis (MB.E 3595) measures $18.2 \mathrm{~mm}$ in length. Additional comparisons, notably of peristome, periproct, and morphology of pores and tuberculation are needed to establish that species' relationship with the genus Echinogalerus.

Occurrence: In Sweden, E. peltifomis was recorded from the mammillatus Zone (uppermost Lower Campanian) and mucronata Zone (lowest Upper Campanian) (Christensen 1975, Kennedy \& Christensen 1997) of the Kristianstad area in
Scania by Lundgren (1888). It was later recorded from the Malen quarry in the Bastad Basin (Wiman 1916). This locality was placed in the lower Upper Campanian by Christensen (1993).

Order Holasteroida Durham \& Melville, 1957

Fa mily Holasteridae Pictet, 1857

Genus Hagenowia Duncan, 1889

Type species: Cardiaster rostratus Forbes, 1852 , by original designation.

\section{Hagenowia blackmorei Wright \& Wright, 1949}

Pl. 2: 4-8

*1949 Hagenowia blackmorei - Wright \& Wright, p. 467, figs 14-16.

1982 Hagenowia blackmorei Wright \& Wright - Gale \& Smith, p. 21, pl. 3, figs 7-8; pl. 4, fig. 6; pl. 6, figs 4, 7, 9; text-fig. 6 (with additional synonymy).

Material: Thirteen rostra from the upper $p i-$ lula Zone to conicalgracilis Zone (Lower Campanian) of Höver (Alemannia) (M. Jäger Colln, Dotternhausen, unregistered; four of these have been selected for SEM observations). A single test (lacking rostrum) from Höver (Alemannia) (H. Reim Colln, Hannover; based on photographs). In addition, the BGR microfossil collections (Hannover) contain a small number of $\mathrm{Ha}$ genowia rostra recovered from various boreholes penetrating the Campanian in the Hannover area.

Description: Rostrum long, slender, clubshaped, well demarcated from body; anterior end of rostrum inflated; high-triangular in cross section, with the lateral sides broader than the dorsal and ventral sides; frontal sulcus shallow with a flattened floor; dorsal ridge of rostrum broad and flattened, distinguishing this species from $H$. elongata (see below); rostral surface densely covered with miliaries; primary tubercles restricted to apex. Genitals 2, 3 not separated from oculars II, IV; number and arrangement of madreporic pores variable.

Discussion: According to M. Jäger (pers. comm. 2000), H. blackmorei ranges throughout the entire Campanian at Höver and Misburg with the exception of its basal portion (lingual quadrata Zone and lower pilula Zone) which is characterised by a much higher clay content. For southern England, Gale \& Smith (1982) noted the appearance of $H$. blackmorei to be confined to the lower part of the Gonioteuthis quadrata Zone (equivalent of the pilula/senonensis to gra- 


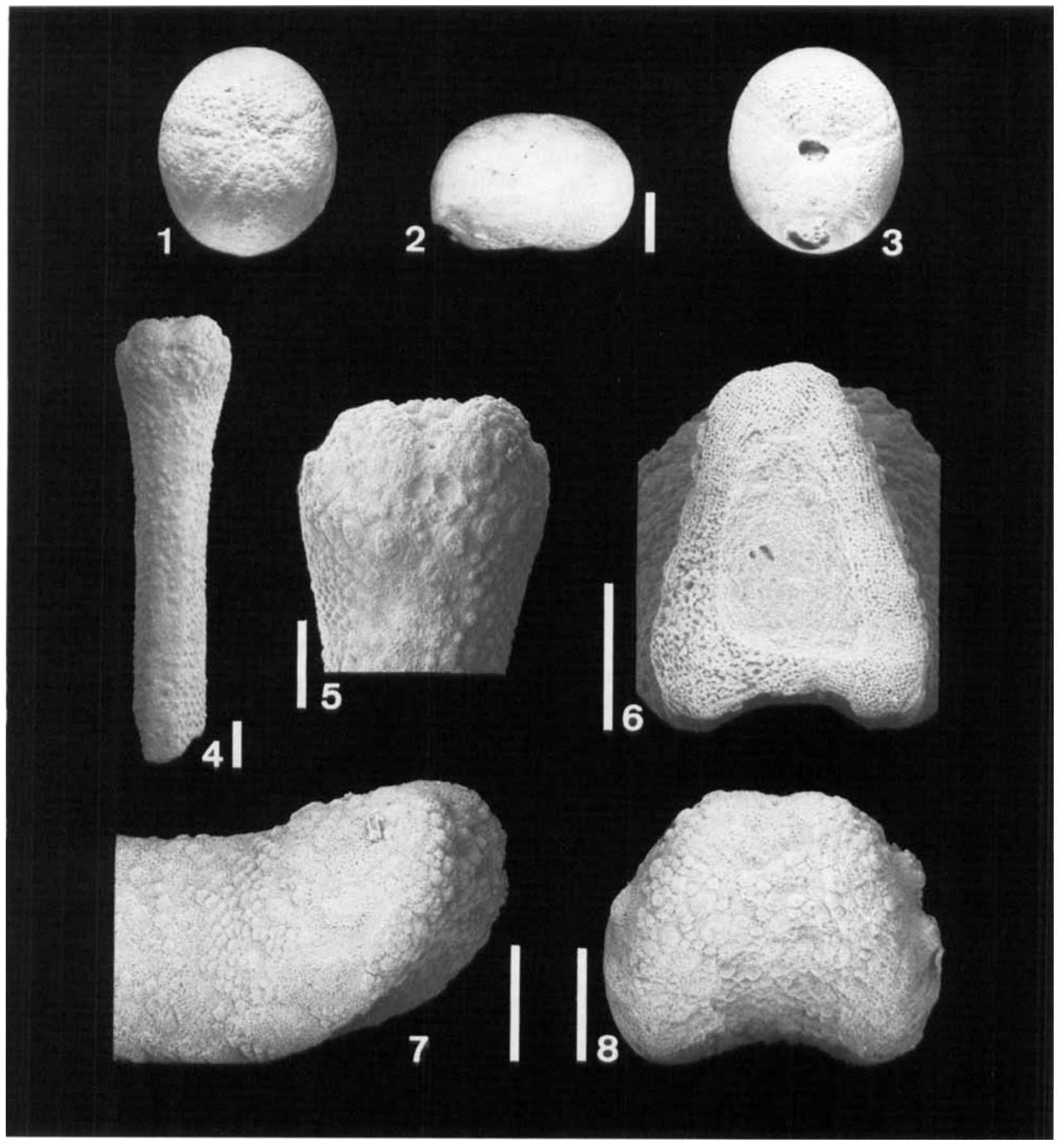

Plate 2. Echinogalerus peltiformis and Hagenowia blackmorei. 1-3. Echinogalerus peltiformis (Wahlenberg, 1821), cast MB.E 3595 in three aspects (1. aboral; 2. lateral; 3. oral). Lower Campanian of Höver (original in U. Frerichs Colln, Hannover, number F1). Scale bar equals $5 \mathrm{~mm}$. 4-8. Hagenowia blackmorei Wright \& Wright, 1949, rostrum. Lower Campanian of Höver (unregistered, M. Jäger Colln, Dotternhausen). SEM photographs. 4. Rostrum, anterior view; 5. Frontal view of aboral system.; 6. Cross section of rostrum showing well-preserved stereom structure and diagnostic shape; 7. Lateral view of apex; 8. Apical view of apex and frontal furrow. Scale bar for all figures equals $500 \mu \mathrm{m}$.

cilis/mucronata Zones of northern Germany, see Christensen 1991), a range corresponding to the occurrence at Höver recorded in the present paper.

Hagenowia sp. ?nov. from the lower Upper Campanian of Liège (NE Belgium; see Jagt 2000: 279, pl. 23, figs 1-4) and Norfolk (England) may be transitional between $H$. blackmorei and $H$. elongata (Brünnich Nielsen 1942) (see
Schmid 1972), from the (upper) Lower Maastrichtian of northern Germany (Kutscher 1978a) and Denmark. This form appears to have the gently concave floor of the sulcus, the narrow dorsal ridge on the rostrum, and the number of gonopores and arrangement/number of madreporic pores in common with $H$. blackmorei. However, genitals 2,3 seem to be separated from culars II, IV, a feature typical of $H$. elongata. The 

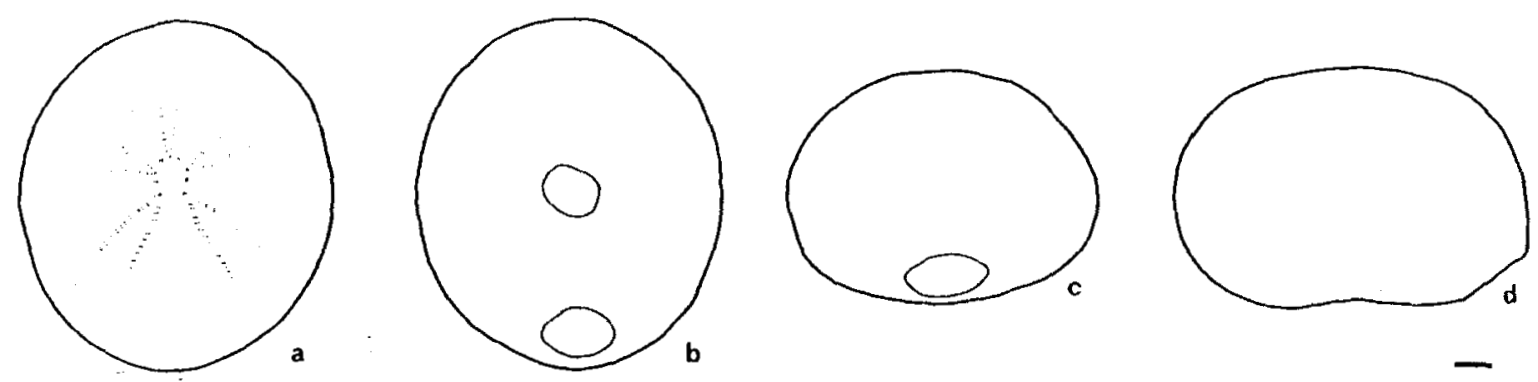

A
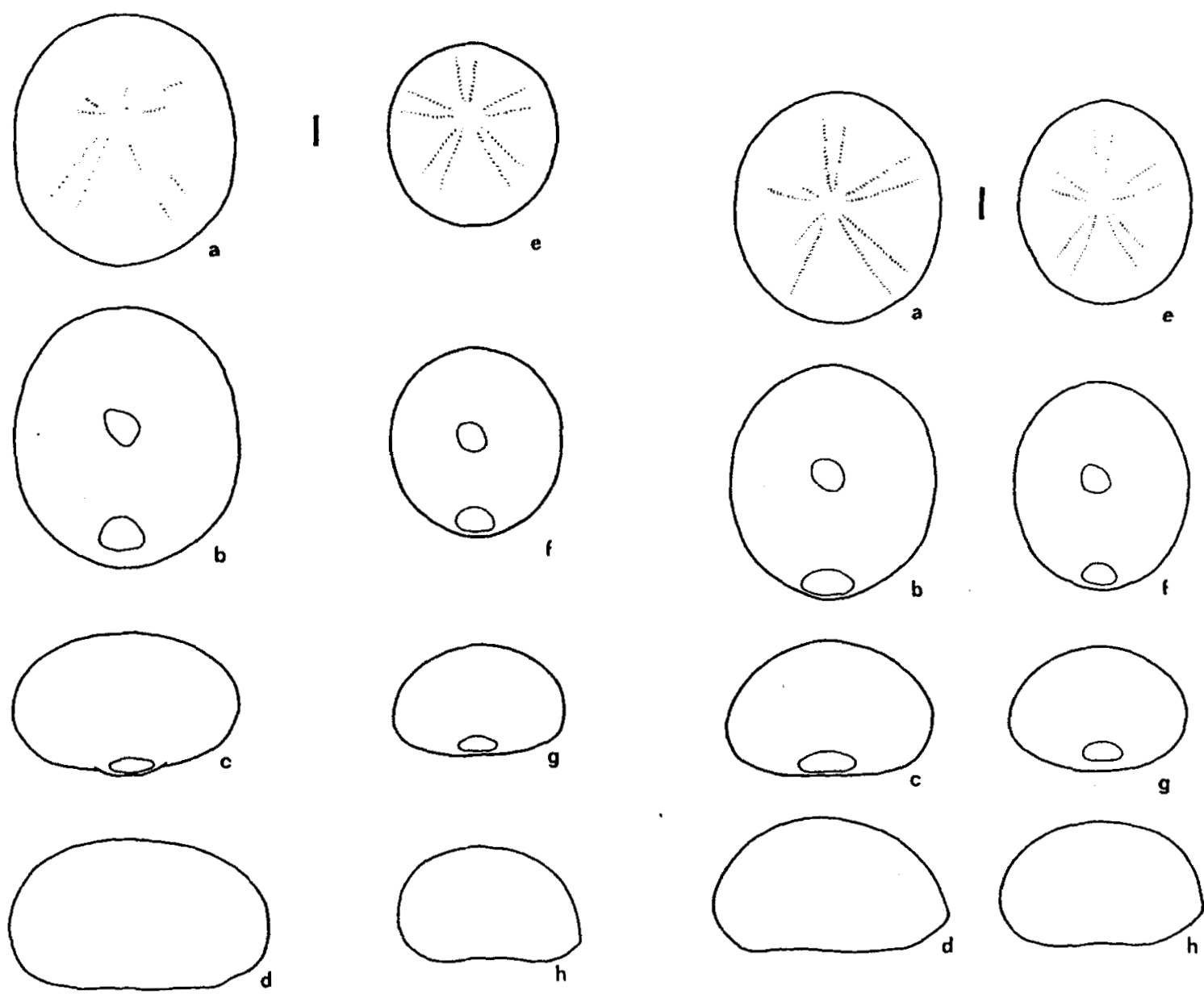

B

C

Fig. 2. Camera lucida drawings of Echinogalerus species discussed in the text. A. Echinogalerus peltiformis (Wahlenberg, 1821) in various aspects, MB.E 3595 (cast; original in U. Frerichs Colln, no. F1); Alemannia quarry (Höver); Lower Campanian. Scale bar equals $2 \mathrm{~mm}$. B. Echinogalerus bueltenensis (Schlüter, 1902) in various aspects. a-d = G. Ernst Colln, no. 30 (Berlin) from the Middle Santonian of GroB Bülten; $e-f=G$. Ernst Colln, no. 71 (Berlin) from the Santonian of Hoheneggelsen. Scale bar equals $2 \mathrm{~mm}$. C. Echinogalerus peltiformis (Wahlenberg, 1821) in various aspects. a-d: 7584-7643/345 from the Lower Campanian of Kjuge (southern Sweden); e-f: unregistered specimen in the De Geer Colln from the Lower Campanian of Barnakälla (southern Sweden); both specimens in collections of the Swedish Museum of Natural History (Stockholm). Scale bar equals $2 \mathrm{~mm}$.

relationship between Hagenowia sp. nov., $H$. blackmorei and $H$. elongata will be discussed in detail elsewhere.

Hagenowia is a highly specialised endofaunal mud dweller previously assumed to have been restricted to the pelagic white chalk facies (e.g.,
Gale \& Smith, 1982) where it often ranks among the most common echinoids (H. Ernst 1984). The occurrence of $H$. blackmorei in the marly limestone facies at Höver and Misburg clearly demonstrates that this species had a much wider ecological range than assumed previously. More- 
over, Hagenowia has a small and fragile tests leading to a limited preservation potential, which makes it more than likely that the isolated rostra are often overlooked by collectors.

Occurrence: $H$. blackmorei is known from the Campanian of Germany and England.

Order Spatangoida Claus, 1876

Suborder Micrasterina Fischer in Moore, 1966

Fa mily Micrasteridae Lambert, 1920

Ge nus Diplodetus Schlüter, 1900

Type species: Diplodetus schlueteri Lambert in Lambert \& Thiéry, 1924 [= Diplodetus brevistella (Schlüter, 1870a)], by subsequent designation of Lambert \& Thiéry (1924).

\section{Diplodetus sp.}

Pl. 3: 4

Material: A single specimen (MB.E 3336) from the upper Lower Campanian (gracilis/mucronata Zone, G/K 24 sensu Khosrovshahian, 1972) at Misburg (Teutonia). The thin test is crushed and incomplete, lacking most of the aboral surface.

Description: Medium-sized spatangoid (length: $37.7 \mathrm{~mm}$; width: $30.3 \mathrm{~mm}$ ), rectangular to coffin-shaped in outline, with a broadly rounded anterior, no frontal sulcus; test truncated posteriorly, anal surface high, overhanging (angle $80^{\circ}$ ); plastron asymmetrical, sternal suture meets the labrum far to the right; labrum relatively large, triangular, with broad contact to the sternal plates of the plastron; periproct small, circular and situated high on the posterior surface; peristome ovoid, relatively small, surrounded by conspicuous phyllode pores; primary tubercles small, scattered and uniform except anteriorly and on the plastron, where tubercle arrangement is slightly denser, tubercles larger and with areole enlargement towards the posterior. A well-defined subanal fasciole is present.

Discussion: Although the aboral surface is missing we assign this specimen to Diplodetus on account of test shape, type of tuberculation, plastronal/labral structure, in combination with the presence of a subanal fasciole. A number of characters clearly distinguishes this specimen from Campanian Micraster species: Micraster differs by its thicker test and cordiform outline, and its symmetrical plastron with a narrow and long labrum which protrudes over the peristome and which is only in little contact with the sternal plates. The peristome of Micraster is positioned at the frontal margin of the test. Moreover, the tuberculation of Micraster is markedly denser and coarser.

The find of Diplodetus sp. in the hemipelagic marly limestone facies of Misburg is surprising. As noted by Stokes (1979), the occurrence of members of the genus Diplodetus was strongly facies controlled, with most species having been recorded from more marginal, often glauconitic biocalcarenitic facies rather than pure, white chalk facies types. Numerous 'species' have been described from the Lower and Upper Campanian of the Münsterland Basin by Schlüter (1870a, b, 1900) but these are in need revision. Hampering such a revision is the general poor preservation of the types and lack of stratigraphically well-documented material. Jagt (2000: 292) noted that too much splitting may have taken place in this genus. For comparison with the Misburg specimen described above, the following taxa of Diplodetus (or Plesiaster, to which some species have originally been attributed), are considered. However, for a more in-depth comparison more material from the Hannover area is needed, especially specimens preserving aboral test features:

Diplodetus brevistella (Schlüter, 1870a: 132; see also Schlüter 1900: 364, pl.15, figs 3-5; RFWUIP Schlüter no. 281) was recorded from the 'Untere Mucronaten-Schichten' (= lower

Plate 3. Peroniaster cotteaui, Hemiaster aquisgranensis and Diplodetus sp. 1-2. Peroniaster cotteaui Gauthier in Peron, 1887; Lower Campanian of Höver. Specimen MB.E 3532. SEM photographs. 1. Aboral view. Scale bar equals 2 mm. 2. Detail of aboral surface. Note peripetalous fasciole and enlarged primary tubercles bordering ambulacrum III. Scale bar equals 1 mm. 3. Peroniaster cotteaui Gauthier in Peron 1887. Juvenile specimen in aboral view, showing a well-developed peripetalous fasciole. Ambulacral pores and gonopores are still lacking. Lowermost Maastrichtian (mB 606, lanceolata Zone), white chalk of Kronsmoor. Scale bar equals $1 \mathrm{~mm}$. 4. Diplodetus sp. Specimen MB.E 3336. View of the preserved oral surface. Upper Lower Campanian (gracilis/mucronata Zone, G/K 24 sensu Khosrovshahian, 1972) at Misburg. Scale bar equals $0.5 \mathrm{~cm}$. 5. Hemiaster aquisgranensis Schlüter 1899. Specimen MB.E 3337, aboral view. Lower Campanian of Höver. Scale bar equals 5 mm. 6. Hemiaster aquisgranensis Schlüter 1899. Specimen MB.E 3789, aboral view. Upper Campanian of Misburg. Scale bar equals $5 \mathrm{~mm}$. 


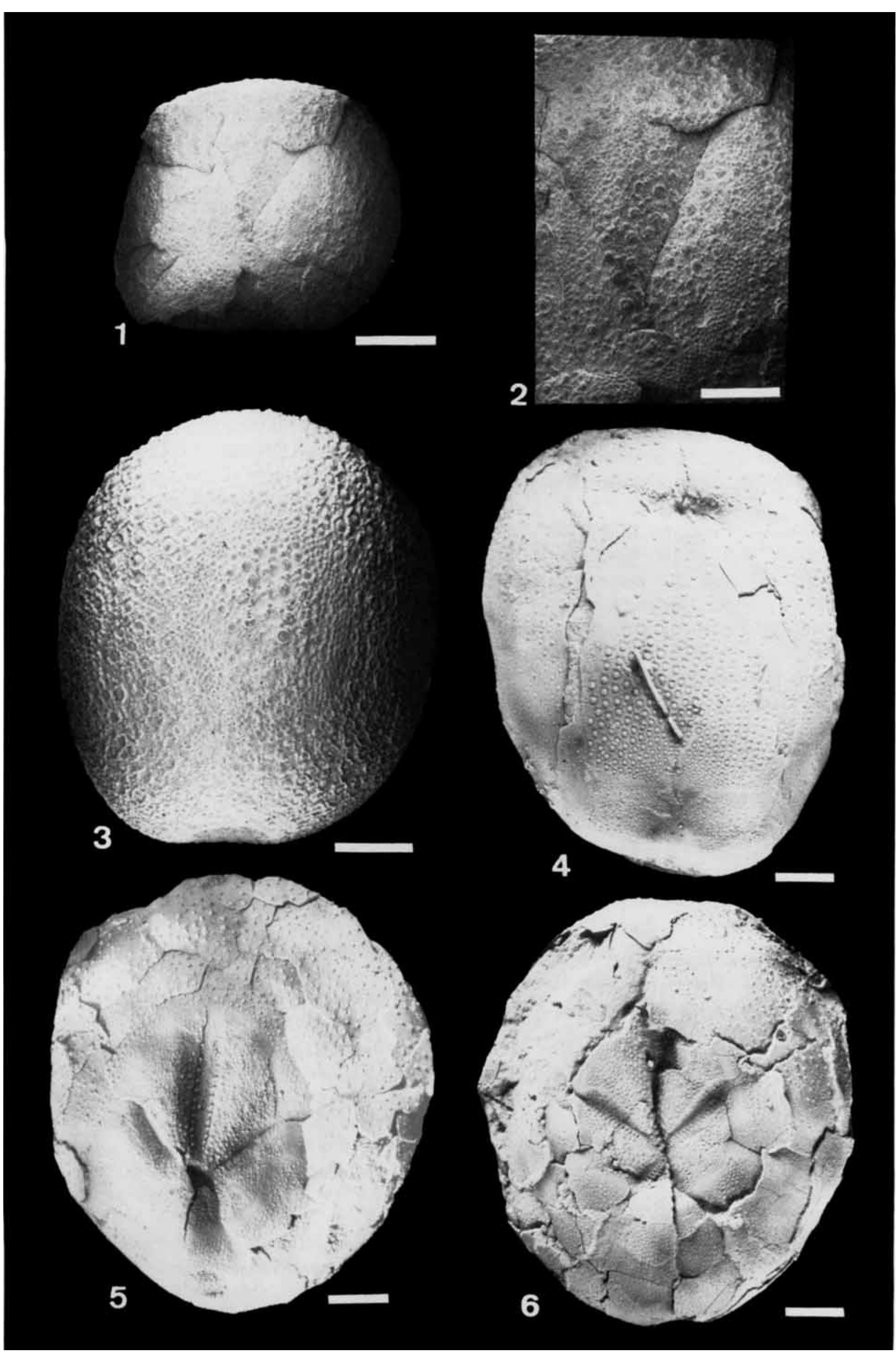


Upper Campanian by inference) at Coesfeld-Sükerhoek and Darup (Münsterland, Germany), i. e. in a glauconitic facies type;

Diplodetus cretaceus (Schlüter, 1870b: 956; see also Schlüter, 1900: 366, pl. 15, fig. 2; RFWUIP Schlüter no. 282a) which is slightly younger, having been described from the 'obere MucronatenKreide, Zone des Heteroceras polyplocum' (= upper Upper Campanian) at Haldem (Germany). This species has recently also been recorded from the upper bipunctatum/roemeri Zone Zone (upper Upper Campanian) of Ahlten, by Niebuhr et al. (1997); both these occurrences refer to the so-called Opoka (siliceous limestone) facies;

Diplodetus? recklinghausenensis Schlüter, 1900 (p. 368 , pl. 15, fig. 1; RFWUIP Schlüter no. 283) is a Late Santonian species from Recklinghausen, also known from the Santonian of Gehrden (Ernst 1973: 99, fig. 6), in a sandy, glauconitic facies type;

Plesiaster minor (Schlüter, 1870a: 132; see also Schlüter 1900: 369, pl. 16, figs 3-5; RFWUIP Schlüter no. 284), now also assigned to Diplodetus, is from the upper Lower Campanian ("... in den jüngsten Schichten mit Actinocamax quadratus ...") of Lette, Coesfeld and Holtwick (Münsterland), as is Plesiaster? cavifer Schlüter 1900 (p. 371, pl. 17, figs 3, 4; RFWUIP Schlüter no. 285a) ("... in der jüngsten Quadraten-Kreide, Zone der Becksia Soekelandi ...") of Lette and Coesfeld. Slightly younger is Plesiaster? cordiformis Schlüter, $1900 \quad$ (p. 372, pl.16, figs 1, 2; RFWUIP Schlüter no. 286), from the "untere Mucronaten-Schichten" near Coesfeld. All these "species" are from glauconitic, comparatively coarse-grained sediments.

Suborder Hemiasterina Fischer in Moore, 1966 Fa mily Hemiasteridae H. L. Clark, 1917

Genus Hemiaster Agassiz in Agassiz \& Desor, 1847

Type species: Spatangus bufo Brongniart 1822 , by subsequent designation of Savin (1903).

\section{Hemiaster gr. aquisgranensis Schlüter, 1899}

Pl. 3: 5-6

*1899 Hemiaster(?) aquisgranensis - Schlüter, p. 123, pl. 10 , figs $1,2$.

*1911 Hemiaster rutoti Lambert, p. 52, pl. 3, figs 3-5.

1995 Hemiaster (Bolbaster) aquisgranensis Schlüter - Jagt \& van Knippenberg, p. 111, figs 1, 2.

1997 Diplodetus cretaceus (Schlüter) - Niebuhr et al., pl. 4, fig. 6 only.
2000 Hemiaster gr. aquisgranensis Schlüter - Jagt, p. 292, pl. 28 , figs $1-6$

Material: Two specimens studied: MB.E 3337 (ex M. Jäger Colln) from Höver (Alemannia, Lower Campanian) and MB.E 3789 (ex. G. Ernst Colln) from Misburg (Teutonia, Upper Campanian ).

Description: Although crushed and partially damaged, both specimens retain fairly well-preserved aboral test surfaces. Thin-tested, almost as broad as long (MB.E. 3337 measures $37.7 \mathrm{~mm}$ in length and $35.0 \mathrm{~mm}$ in width), circular in outline, no frontal sulcus. Apical system slightly anterior. Plastron with nearly symmetrical sternal plates. Labrum, periproct and peristome not preserved, but it appears that the position of the peristome was submarginal. Petals well developed, length of anterior ambulacra is $44 \%$ of length of posteriors. Pores in petals slit-like. Frontal ambulacrum narrow and slightly sunken within the peripetalous fasciole. Here, pores are oblique isopores which show a prominent interporal partition. Peripetalous fasciole well-developed, narrow. Primary tubercules on the aboral side are large and scattered, inside the peripetalous fasciole smaller and more densely arranged. On the oral surface, primary tubercles are small and scattered, except on the plastron.

Discussion: For the time being, usage of the name $H$. aquisgranensis is preferred for mediumto large-sized hemiasterids with non-scrobicular tuberculation. The type is a flint-preserved internal mould from strata of undoubted Late Maastrichtian age. Large collections from the upper Gulpen and lower Maastricht formations (inclusive of the Kunrade Limestone facies) of the type area of the Maastrichtian stage are available, and these clearly demonstrate that $H$. rutoti is a junior synonym. Van der Ham (1985) and Jagt (2000), who both referred material of Early Campanian to Late Maastrichtian age to $H$. aquisgranensis, stressed that this was a heterogeneous lot, and that various test morphologies might be separated on the basis of biometric analyses in the future. Pending such a revision, all material is here assigned to $H$. aquisgranensis. From the Hannover-Misburg area, this hemiasterid was first recorded by Jagt \& van Knippenberg (1995).

Smith \& Jeffery (2000) tentatively synonymised $H$. aquisgranensis and $H$. rutoti with Hemiaster stella (Morton, 1830: 245, pl. 3, fig. 11), originally recorded from the Paleocene Vincentown Sand of New Jersey (USA). 
Occurrence: $H$. aquisgranensis is well known from the Campanian/Maastrichtian of Limburg, Liège, Aachen and the western Münsterland Basin. In our context, it is interesting, that it was recently found in the upper Upper Campanian (polyplocum to bipunctatum/roemeri Zones) of the nearby locality Ahlten, where it occurs in the spiculitic chalk of the so-called Opoka facies.

\section{Genus Peroniaster Gauthier in Peron, 1887}

Type species: Peroniaster cotteaui Gauthier in Peron 1887 , by monotypy.

\section{Peroniaster cotteaui Gauthier in Peron, 1887}

Pl. 3: 1-3

*1887 Peroniaster cotteaui - Gauthier in Peron, p. 390, pl. 7, figs $1-7$.

1978b Peroniaster cotteaui Gauthier - Kutscher, p. 1025, pl. 1.

2000 Hemiaster sp. indet. 4 - Smith \& Jeffery, p. 327.

2001 Bolbaster cotteaui (Gauthier) - Néraudeau \& Odin, p. 624, pl. 3, figs 60-62.

(non) 1974 Peroniaster cf. cotteaui Gauthier - Ernst \& Schulz p. 24, fig. 6 .

Material: Two specimens (MB.E 3532, 3533) from Höver (Alemannia, upper Lower Campanian).

Description: Test small (in MB.E 3532 length is $8.2 \mathrm{~mm}$ and width is $7.1 \mathrm{~mm}$ ), nearly circular in outline; no frontal sulcus. Oral and aboral surfaces flattened, test highest anterior of centre; anterior surface steep, inclined ca. $85^{\circ}$ so that the periproct is just visible from above. Plastron wide, slightly inflated, sternal plates almost symmetrical; peristome submarginal, kidney-shaped with distinct rim, with the labrum forming a prominent lip projecting slightly over peristome; apical disc damaged, but apparently positioned centrally; with the exception of the periplastronal area, the test is densely covered with large, perforate scrobicular tubercles; periplastronal areas show marked labyrinthic ornamentation. Frontal ambulacrum bordered laterally by single rows of enlarged tubercles; peripetalous fasciole wide and well developed. Aborally, paired ambulacra are non-petaloid, flush with test; pores reduced or altogether lacking. Within the peripetalous fasciole, the frontal ambulacrum is weakly sunken and bears a low number of tiny, circular isopores. Phyllode pores are missing.
Discussion: Although both specimens are crushed and have a slightly abraded test surface, preservation is such that they may be identified at species level with confidence. Previously, the status of the genus Peroniaster has often been the subject of controversy. In Gauthier's original illustration of the species, gonopores cannot be made out. Duncan (1889) and Fischer (1966) considered it to be synonymous with Hemiaster and Mortensen (1950) opined that Peroniaster cotteaui might be a juvenile of an unknown Hemiaster. Recently, Smith \& Jeffery (2000) adopted Mortensen's point of view while Néraudeau \& Odin (2001) assigned it to the genus Bolbaster, generally considered to be a subgenus of Hemiaster. On the other hand, Ernst \& Schulz (1974) and Kutscher (1978b) provided illustrations of Peroniaster with open and clearly visible gonopores and noted that specimens studied by them were indeed small but without doubt represented adult echinoids.

Peroniaster cotteaui appears to be a markedly paedomorphic species with juveniles lacking developed gonopores, albeit similar in overall shape to adult ones (see also Pl. 3: 3). The largest known representative of the genus is Peroniaster sp. from the Middle Coniacian of Lägerdorf (maximum test length $17.5 \mathrm{~mm}$ ); this also has non-petaloid and almost completely reduced aboral ambulacra (Ernst \& Schulz 1974).

Peroniaster is distinguished from Bolbaster in lacking petaloid ambulacra, in both the juvenile and adult stage. In the latter, petals form at an early stage of postlarval development at which ambulacral pores are already well-developed and slit-like (see Jagt 2000: pl. 29, figs 5-8).

Psephoaster McNamara, 1987, a small globular hemiasterid from the Cainozoic of Australia also has non-petaloid ambulacra with round isopores and a frontal ambulacrum which is flush with the test. It differs from Peroniaster in its larger size as well as in features of tuberculation, and in having a narrower peripetalous fasciole and more numerous pores in the paired ambulacra.

Occurrence: Santonian to Maastrichtian of Spain, France and Germany. In Germany, P. cotteaui occurs sporadically in the chalk facies at Lägerdorf and Kronsmoor, ranging from the Santonian to the Lower Maastrichtian. The species is markedly commoner in the Lower Maastrichtian of Rügen (M. Kutscher, pers. comm. 1999; pers. obs.). 


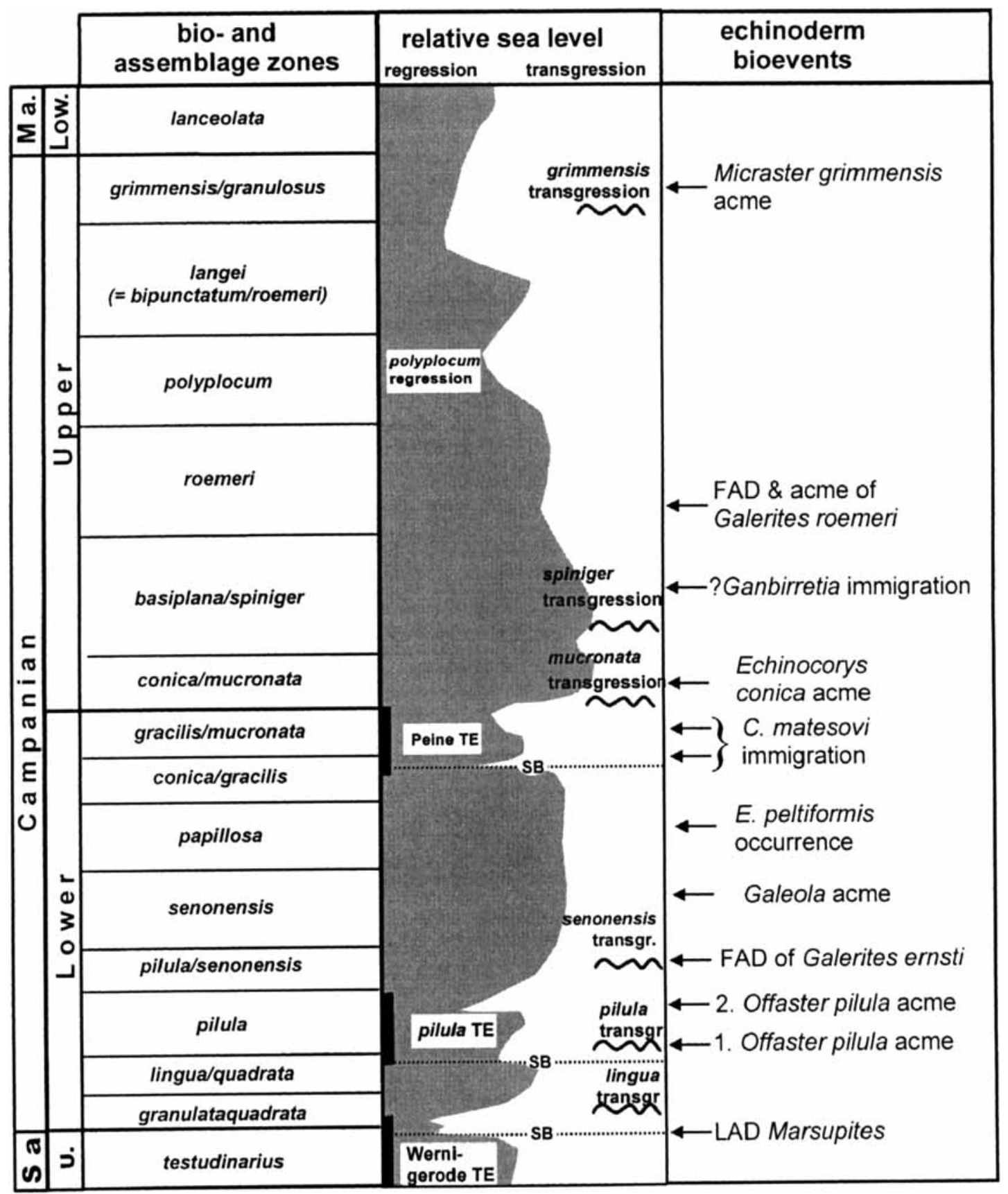

Fig 3. Echinoderm bio-events in the Campanian of northern Germany in relation to eustatics and Subhercynian tectonic phases (sea-level curve and sequence-stratigraphic interpretation compiled after Mortimore et al. [1998], Niebuhr et al. [1997] and unpublished data of G. Ernst). Abbreviations: FAD: First appearance datum; LAD: Last appearance datum; SB: Sequence boundary; TE: Tecto-event.

\section{The ecological reasons of rarity in the fossil record}

Most of our knowledge of fossil (and extant!) benthic communities comes from the study of common species, but many species are rare. Sealevel driven changes in the relative abundance of common chalk echinoids such as Echinocorys and Micraster were already recognised by Ernst (1970a) and later by Néraudeau \& Villier (1997). However, all the echinoid species discussed in the present paper are extraordinarily rare in the Campanian strata of the Lower Saxony Basin. How may their rarity be explained? To answer this, we need to address the various ecological and taphonomic processes which may contribute to this picture. Of particular concern is the bias in our knowledge of the structure and ecology of benthic palaeocommunities including biotic interactions, because rare and common species may, and indeed often do, differ in more ways than just their abundance patterns. 
Below, we list the four most important processes that may lead to rarity of species in the fossil record, viz. ecological, physical, taphonomic processes as well as sampling biases. These may act together and reinforce each other:

1. Rarity in the fossil record created by the palaeobiology and -ecology of species in a given community (see also Gaston 1996):

Low dispersal abilities

Low reproductive effort

Unfavourable ecological conditions (e.g. low food supply, concurrence/predation pressure)

Patchiness

Temporal persistance (= taxon age)

Endemism

Ranges size.

2. Rarity created by events

Short-term changes of sea level, ocean circulation, climate, food supply may cause shortterm invasions of species from neighbouring palaeobiogeographic realms or lead to expansions of distribution ranges. Generally, these 'intruder' species or 'vagrants' are unable to establish populations over a longer period (pulse appearance, Ernst \& Wood 1996).

3. Rarity created by taphonomy

Low preservation potential of small or fragile species or species with weakly mineralised hard parts also leads to rarity in the fossil record (this is also the case for early ontogenetic stages as juveniles are markedly underrepresented in the fossil record, e.g., Dodd et al. 1985). These are occasionally preserved under sheltered conditions, e.g in fossil traps (for instance, cephalopod body chambers), or in obrution deposits (Konservat-Lagerstätten). This shows that, additionally to taxonomy and ontogeny, preservation potential is strongly controlled by the sedimentary regime which is intimately related to water depth (e.g., Parsons \& Brett 1991, Smith et al. 2001).

4. Rarity as a sampling artefact

Sampling methods can also create rarity, e.g. if small or fragmented species are not recognised or overlooked at outcrop or if non-standardised sampling methods are used (nonquantitative sampling methods, in particular).

Applying the above to the irregular echinoids from Höver and Misburg described in the present paper, results in the following interpretation:

Conulus matesovi probably is an intruder (vagrant) from southeast Europe (Caucasus) while the origin of Echinogalerus peltiformis remains unknown, since it occurs in younger strata in Southern Sweden. However, we suggest that it intruded from the northern margin of the North Sea Basin, where it is markedly more abundant in nearshore coarse-grained arenitic limestones. Although ranging throughout the Campanian of the Lower Saxony Basin, Hagenowia blackmorei is a rare species; it is much commoner in the pelagic white chalk facies. Its rarity is probably a function of suboptimal ecological conditions (clay content of the substrate?). Isolated rostra are probably also often overlooked by collectors, adding a sampling bias. The genus Hagenowia is endemic to the North Sea Basin. Both Diplodetus sp. and Hemiaster aquisgranensis were probably occasional intruders from more neritic environments elsewhere. Both share the same burrowing and feeding habits (shallow infaunal selective deposit feeders). The latter species is fairly common in neritic sediments (arenitic/spiculitic chalks and limestones) of the western Münsterland Basin, in the Aachen area and in the Liège-Limburg Basin. For Peroniaster cotteaui we may assume that this small and delicate species had a limited preservation potential in the marly limestone facies where small echinoids are commonly crushed due to compaction and tests surfaces often show signs of dissolution; It is also rare in the pelagic white chalk of the North Sea Basin, but here its preservation is excellent (see Pl. 3: 3). It might be an intruder from southwestern Europe, where it is fairly common in the uppermost Campanian at Tercis les Bains (Landes, France) (see Néraudeau \& Odin 2001).

Naturally, the above picture cannot be but preliminary. To explain why some species in the fossil record are rare we need to know much more about their palaeobiology, community interactions, palaeobiogeographic distribution, stratigraphic ranges, facies dependence, taphonomic processes and basin history of any area studied. In addition, proper sampling methods need to be considered and robust data bases developed so as to minimise sampling biases. The echinoid material described in the present paper is the result of more or less random sampling, generally without strict stratigraphic control. Much work still needs to be done for this picture to become more detailed and reliable.

\section{Acknowledgements}

For loan or donation of material, preparation of photographs and supply of items of literature we wish to thank J. Bergström (Swedish Museum of Natural History, Stockholm), W. K. Christensen (Copenhagen), R. W. Dortangs (Amsten- 
rade), G. Ernst ( $\dagger$ ) (Berlin), J, van den Essen (Venlo-Blerick), U. Frerichs (Langenhagen), Ingela Chef Holmberg (Swedish Museum of Natural History, Stockholm), J. Idema (Ouderkerk aan de Amstel), W. Judenhagen (Wolfsburg), A. Kroh (Viena), D. Licht (Vinkeveen), A. B. Smith (Natural History Museum, London) and H.-V. Thiel (Düsseldorf), For improvements and review of the manuscript we are delighted to thank M. Aberhan (Berlin), G. Arratia (Berlin), W. K. Christensen (Copenhagen), and A. Kroh (Vienna).

\section{References}

Agassiz, L. \& Desor, E. 1847. Catalogue raisonné des espèces, des genres, et des familles d'échinides. - Annales de la Société naturelle (3)7: 129-168; (3)8: 5-35, 355-380.

Ali-Zade, A. A., Aliev, G. A., Aliev, M. M., Aliyulla, Kh. \& Khalilov, A. G. 1988. Melovaia fauna Azerbaidzhana. 455 pp., Akademiya Nauk Azerbaidzhanskoi SSSR, Institut Geologii im. I. M. Gubkina, Izdatelstvo ELM, Baku (in Russian).

Brongniart, A. 1822. Sur quelques terrains de craie hors du Bassin de Paris. In Cuvier, G. \& Brongniart, A.: Description géologique des environs de Paris 2: 316-337, Dufour $\&$ d'Ocagne, Paris.

Brünnich Nielsen, K. 1926. Kalken paa Saltholm Danmarks geologiske Undersögelse, $4^{\text {th }}$ series, 1 (20): 1-23.

Christensen, W. K. 1975. Upper Cretaceous belemnites from the Kristianstad area in Scania. - Fossils and Strata 7: $1-69$.

Clark, H. L. 1917. Hawaiian and other Pacific Echini. The Echinoneidae, Nucleolitidae, Urechinidae, Echinocorythidae, Calymnidae, Pourtalesiidae, Palaeostomatidae, Aeropsidae, Palaeopneustidae, Hemiasteridae and Spatangidae. - Memoirs of the Museum of Comparative Zoology of Harvard University 46: 81-283.

- 1925. A catalogue of the Recent sea-urchins (Echinoidea) in the collections of the British Museum (Natural History). 250 pp., British Museum (Natural History), London.

Claus, C. F. W. 1876. Grundzüge der Zoologie. 822 pp., N.G. Elwert'sche Universitäts Buchhandlung, Marburg/ Leipzig.

- 1880. Grundzüge der Zoologie. vii $+821+522$ pp., N.G. Elwert'sche Universitäts Buchhandlung, Marburg/Leipzig.

Cotteau, G. \& Gauthier, V. 1895. Mission scientifique en Perse par J. de Morgan, 3. Études géologiques, $2-\mathrm{Pa}$ léontologie, 1. Échinides fossiles. - 142 pp., E. Leroux, Paris.

Desor, E. 1842. Des Galérites. In Agassiz, L. Monographies d'Échinodermes vivans et fossiles 3: iv $+1-94$, Petitpierre, Neuchâtel.

Dodd, J. R., Alexander, R. R. \& Stanton, R. J., Jr. 1985. Population dynamics in Dendraster, Merriamaster, and Anadara from the Neogene of the Kettleman Hills, California. Palaeogeography, Palaeoclimatology, Palaeoecology 52: $61-76$.

Duncan, P. M. 1889. A Revision of the genera and great groups of the Echinoidea. - Journal of the Linnean Society London (Zoology) 23: 1-311.

Durham, J. W. \& Melville, R. V. 1957. A classification of echinoids. - Journal of Paleontology 31: 242-272.

Emst, G. 1970a. Faziesgebundenheit und Ökomorphologie bei irregulären Echiniden der nordwestdeutschen Oberkreide. - Paläontologische Zeitschrift 44: 41-62.

- 1970b. Zur Stammesgeschichte und stratigraphischen Bedeutung der Echiniden-Gattung Micraster in der nordwestdeutschen Oberkreide. - Mitteilungen aus dem Geologisch-paläontologischen Institut der Universität Hamburg 39: 117-135.
- 1970c. The stratigraphical value of the echinoids in the boreal Upper Cretaceous. - Newsletters on Stratigraphy 1: $19-34$.

- 1971. Biometrische Untersuchungen über die Ontogenie und Phylogenie der Offaster/Galeola-Stammesreihe (Echin.) aus der nordwesteuropäischen Oberkreide. Neues Jahrbuch für Geologie und Paläontologie Abhandlungen 139: 169-225.

- 1972. Grundfragen der Stammesgeschichte bei irregulären Echiniden der nordwesteuropäischen Oberkreide. - Geologisches Jahrbuch A4: 63-175.

- 1973. Die Echiniden-Fauna des Santon der Gehrdener Berge. - Berichte der naturhistorischen Gesellschaft zu Hannover 117: 79-102.

- 1975. Stratigraphie, Fauna und Sedimentologie der Oberkreide von Misburg und Höver bei Hannover (Exkursionsführer). - Mitteilungen aus dem Geologisch-paläontologischen Institut der Universität Hamburg 44: 69-97.

Ernst, G., Niebuhr, B. \& Rehfeld, U. 1997a. HPCF II at Misburg. In Mutterlose, J., Wippich, M. G. E. \& Geisen, M. (eds). Cretaceous Depositional Environments of NW Germany. - Bochumer geologische und geotechnische Arbeiten 46: 77-82.

- 1997b. Germania IV quarry at Misburg. In Mutterlose, J., Wippich, M. G. E. \& Geisen, M. (eds.). Cretaceous Depositional Environments of NW Germany. - Bochumer geologische und geotechnische Arbeiten 46: 83-87.

- 1997c. Teutonia I quarry at Misburg. In Mutterlose, J., Wippich, M. G. E. \& Geisen, M. (eds). Cretaceous Depositional Environments of NW Germany. - Bochumer geologische und geotechnische Arbeiten 46: 89-95.

Ernst, G., Schmid, F. \& Klischies, G. 1979. Multistratigraphische Untersuchungen in der Oberkreide des Raumes Braunschweig-Hannover. In Wiedmann, J. (ed.). Aspekte der Kreide Europas. - International Union of Geological Sciences (A)6: 11-46.

Ernst, G., Schulz, M.-G. \& Schmid, F. 1971. Die Entwicklungsgeschichte der hochspezialisierten Echiniden-Reihe Infulaster-Hagenowia in der borealen Oberkreide. - Paläontologische Zeitschrift 45: 120-143.

Ernst, G. \& Schulz, M.-G. 1974. Stratigraphie und Fauna des Coniac und Santon im Schreibkreide-Richtprofil von Lägerdorf (Holstein). - Mitteilungen aus dem GeologischPaläontologischen Institut der Universität Hamburg 43: $5-60$.

Ernst, G. \& Seibertz, E. 1977. Concepts and Methods of Echinoid Biostratigraphy. In Kauffman, E. G. \& Hazel, J. E. (eds). Concepts and Methods of Biostratigraphy: 541-566, Dowden, Hutchinson \& Ross, Inc., Stroudsburg.

Ernst, G. \& Wood, C. J. 1996. Migration events and faunal successions in a sequence stratigraphical context exemplified by selected Upper Cretaceous fossil groups. In Fifth International Cretaceous Symposium and Second Workshop on Inoceramids, Freiberg/Saxony, Germany - September 16-24, 1996, Abstract Volume: 23-24, Freiberg University of Mining and Technology, Freiberg.

Ernst, H. 1984. Bericht über eine Großprobenserie im Schreibkreide-Richtprofil von Lägerdorf/Kronsmoor (MConiac bis U-Maastricht). - Mitteilungen aus dem Geologisch-Paläontologischen Institut der Universität Hamburg 57: 137-145.

Fischer, A. G. 1966. Spatangoids. In Moore, R. C. (ed.). Treatise on Invertebrate Paleontology, Part U, Echinodermata 3(2): U543-U628, Geological Society of America, Boulder/University of Kansas Press, Lawrence.

Forbes, E. 1852. Figures and descriptions illustrative of British organic remains. Memoirs of the Geological Survey of the United Kingdom 4: $1-4$.

Frerichs, U. 1989. Die Micraster aus dem Campan von Misburg und Höver. - Arbeitskreis Paläontologie Hannover 17: $151-167$. 
- 1995. Die kleinen irregulären Seeigel aus dem Untercampan von Höver und Misburg. - Arbeitskreis Paläontologie Hannover 23: 1-19.

Gale, A. S. \& Smith, A. B. 1982. The palaeobiology of the Cretaceous irregular echinoids Infulaster and Hagenowia. - Palaeontology 25: 11-42.

Gallemí, J., López, G., Martínez, Muñoz, J. \& Pons, J. M. 1995. Distribution of some Campanian and Maastrichtian macrofaunas in southeast Spain. - Cretaceous Research 16: $257-271$.

Gaston, K. J. 1996. What is rarity? In Kunin, W. E. \& Gaston, K. J. (eds): The Biology of Rarity: Causes and Consequences of Rare-common Differences. Population and Community Biology Series 17: 30-47, Chapman \& Hall, London.

Ham, R. W. J. M. van der 1985. De zeeëgel Hemiaster aquisgranensis Schlüter, 1899 in het Campaniën en het Maastrichtiën van Zuid-Limburg en aangrenzende delen van België en Duitsland. - Natuurhistorisch Maandblad 74: $147-156$.

Ham, R. W. J. M. van der \& Birgelen, M. J. van (in press). The echinoid genus Echinogalerus in the Maastrichtian type area. In Jagt, J. W. M., Schulp, A. S. \& Graaf, D. T. (eds). The 150th anniversary of the Maastrichtian Stage: a celebratory conference. - Netherlands Journal of Geosciences.

Jagt, J. W. M. 2000. Late Cretaceous-Early Palaeogene echinoderms and the K/T boundary in the southeast Netherlands and northeast Belgium - Part 4: Echinoids. Scripta Geologica 121: 181-375.

Jagt, J. W. M. \& Knippenberg, P. H. M. van 1995. A note on a late Campanian hemiasterid echinoid from HannoverMisburg (N Germany). - Neues Jahrbuch für Geologie und Paläontologie, Monatshefte 1995 (2): 111-117.

Jeffery, C. H. 1997. All change at the Cretaceous-Tertiary boundary? Echinoids from the Maastrichtian and Danian of the Mangyshlak Peninsula, Kazakhstan. - Palaeontology 40: 659-712.

Kennedy, W. J. \& Christensen, W. K. 1997. Santonian to Maastrichtian ammonites from Scania, southern Sweden. - Fossils and Strata 44: 75-128.

Khosrovschahian, R. 1972. Feinstratigraphische und faziesanalytische Untersuchungen im Campan von Misburg bei Hannover.- Doctoral dissertation, Technische Universität Braunschweig: $84 \mathrm{pp}$.

König, C. D. E. 1825 . Icones fossilium sectiles 1.4 pp., London (Published by the author).

Küchler, T. 2000. Upper Cretaceous of the Barranca (Navarra, northern Spain); integrated litho-, bio- and event stratigraphy. Part II: Campanian and Maastrichtian. - Acta geologica polonica 50: $441-499$.

Kutscher, M. 1978a. Neue Echiniden aus dem Unter-Maastricht der Insel Rügen. I. Holasteridae Durham \& Melville [sic]. - Zeitschrift für geologische Wissenschaften Berlin 6: $627-639$.

- 1978b. Neue Echiniden aus dem Unter-Maastricht der Insel Rügen. II. Spatangoida Claus, 1876. - Zeitschrift für geologische Wissenschaften Berlin 6: 1025-1037.

- 1986. Neue Echiniden aus dem Unter-Maastricht der Insel Rügen. Conulus magnificus (d'Orbigny, 1853). Zeitschrift für geologische Wissenschaften Berlin 14: 325-329.

Lambert, J. 1898. Note sur les Échinides de la craie de Ciply. - Bulletin de la Société belge de Géologie, de Paléontologie et d'Hydrologie 11(1897): 141-190.

- 1905. In Doncieux, L. Catalogue descriptif des fossiles nummulitiques de l'Aude et de l'Hérault. Première partie. Montagne Noire et Minervois. - Annales de l'Université de Lyon 17: 1-184.

- 1911. Description des Échinides crétacés de la Belgique principalement de ceux conservés au Musée royal de Bruxelles. II. Échinides de l'étage Sénonien. - Mémoires du Musée royal des Sciences naturelles de Belgique 4: $1-81$.
- 1920. Échinides fossiles des environs de Santander recueillis par M. L. Mengaud, II. - Annales de la Société linnéenne de Lyon 67: 1-32.

- 1935. Sur quelques échinides fossiles de Valence et d'Alicante communiqués par M. le Prof. Darder Pericás. Boletín de la Sociedad Española de Historia Natural 35: $359-371$.

Lambert, J. \& Thiéry, P. 1909-1925. Essai de nomenclature raisonné des Échinides. iii +80 pp. (1909); 81-160 (1910); 161-240 (1911); 241-320 (1914); 321-384 (1921); 385-512 (1924); 513-607 (1925), L. Ferrière, Chaumont.

Leske, N. G. 1778. Jacobi Theodori Klein Naturalis dispositio Echinodermatum, edita et descriptionibus novisque inventis et synonymis auctorum aucta. xxii +278 pp., G.E. Beer, Lipsiae.

Lundgren, B. 1888: List of the fossil Faunas of Sweden. III: Mesozoic. - Palaeontological Department of the Swedish state Museum (Natural History): 6-20; Stockholm.

Malinowska, L. (ed.) 1989. Geology of Poland, 3. Atlas of guide and characteristic fossils, Part 2c. Mesozoic, Cretaceous. 422 pp., Publishing House Wydwanictwa Geologiczne.

Mantell, G. A. 1822. The fossils of the South Downs, or illustrations of the geology of Sussex. 327 pp., Lupton Relfe, London.

McNamara, K. J. 1987: Taxonomy, evolution, and functional morphology of Southern Australian Tertiary hemiasterid echinoids. - Palaeontology 30 (2): 319-352.

Melikov, O. G. \& Endel'man, L. G. 1963. Novyi morskoi ezh iz nizhiego maastrikhta kavkaza. - Paleontologichesky Zhurnal 1963 (4): 135-138.

Moore, R. C. (ed.). Treatise on Invertebrate Paleontology, Part U, Echinodermata 3 (2): U543-U628, Geological Society of America, Boulder/University of Kansas Press, Lawrence.

Mortensen, T. 1950. A monograph of the Echinoidea. Vol. 5 (1), Spatangoida I, 432 pp., 25 pls. C.A. Reitzel, Kobenhavn.

Mortimore, R., Wood, C., Pomerol, B. \& Ernst, G. 1998. Dating the phases of the Subhercynian tectonic epoch: Late Cretaceous tectonics and eustatics in the Cretaceous basins of northern Germany compared with the Anglo-Paris Basin. - Zentralblatt für Geologie und Paläontologie (1) 11/12: 1349-1401.

Morton, S. G. 1830. Synopsis of the organic remains of the ferrigenous sand formation of the United States, with geological remarks. Part 2. - American Journal of Sciences 18: $243-250$.

Moskvin, M. M. 1959. (ed.). Atlas verkhnemelovoj fauny severnogo Kavkaza u Kryma. Gostoptechisdat, Moskva. 453 pp.(In Russian).

Moskvin, M. M. \& Endel'man, L. G. 1972. Pozdnemelovye morskie ezhi Mangyshlaka i ikh stratigraficheskoe znachenie. In Biostratigrafiia mezozoiskikh otlozheniya neftegazonosnyh oblasti SSSR: 3-10. Akademiya Nauk SSSR, Institut Geologii i Razrabotki Goriuchikh Iskopaemykh, Moskva. (In Russian).

Moskvin, M. M., Solovjev, A. N. \& Endel'man, L. G. 1980. [Class Echinoidea]. In Viskova, L. A. (ed.). [Evolution and Change of Invertebrates at the Mesozoic/Cenozoic Boundary]: 116-175, Izdatel'stvo 'Nauka', Moskva. (In Russian).

Néraudeau, D. \& Odin, G. S. 2001. Echinoids from the geological site at Tercis les Bains (Landes, SW France). In Odin, G. S. (ed.). The Campanian-Maastrichtian Stage Boundary. Characterisation at Tercis les Bains (France) and Correlation with Europe and other Continents: 612-634, Elsevier, Amsterdam.

Néraudeau, D. \& Villier, L. 1997. Enregistrement des fluctuations environnementales par les échinides irréguliers de la craie Campanienne de Charente-Maritime (SO France). - Annales de la Société géologique du Nord (2) 5: $175-179$. 
Niebuhr, B., Volkmann, R. \& Schönfeld, J. 1997. Das obercampane polyplocum-Event der Lehrter Westmulde (Oberkreide, N-Deutschland): Bio-/Litho-/Sequenzstratigraphie, Fazies-Entwicklung und Korrelation. - Freiberger Forschungshefte C468: 211-243.

Novák, O. 1887. Studien an Echinodermen der böhmischen Kreideformation. I. Die irregulären Echiniden der Cenomanstufe. - Abhandlungen der kaiserlichen böhmischen Gesellschaft für Wissenschaften (7) 2: 1-47.

d'Orbigny, A. D. 1853-1860. Paléontologie française. Description des animaux invertébrés. Terrain crétacé 6 , Échinoïdes irréguliers. 596 pp., Masson, Paris.

Parsons, K. M. \& Brett, C. E. 1991. Taphonomic processes and biases in modern marine environments: an actualistic approach on fossil assemblage preservation. In Donovan, S. K. (ed.). The Process of Fossitisation: 22-65. Columbia University Press, New York.

Peron, A. 1887. Notes pour servir à l'histoire du terrain de craie dans le sud-est du Bassin anglo-parisien. Bulletin de la Société des Sciences historiques et naturelles de l'Yonne 41: 114-424.

Pictet, F.-J. 1857. Traité Élémentaire de Paléontologie 4. 768 pp., Baillière, Paris.

Reyment, R. A. 1976. Biographical Notes on Göran (Georg) Wahlenberg. - De Rebus 3: 1-11.

Poslavskaia, N. A. \& Moskvin, M. M. 1959. Klass Echinoidea. Morskie ezhi. In Moskvin, M. M. (ed.). Atlas verkhnemelovoj fauny severnogo Kavkaza u Kryma: 242-304, Gostoptechisdat, Moskva.

Radig, F. 1973. Beiträge zur Kenntnis der höheren Oberkreide der Baskischen Depression (Nordspanien) und ihrer Echinozoen-Fauna. - Erlanger geologische Abhandlungen 94: $1-68$

Roemer, F. A. 1840-1841. Die Versteinerungen des norddeutschen Kreidegebirges. iv $+1-48$ (1840), 49-145 (1841), Hahn'sche Hofbuchhandlung, Hannover.

Savin, L. 1903. Catalogue raisonnée des échinides fossiles de la Savoie. - Bulletin de la Société d'Histoire naturelle de Savoie (2) 8: 59-249.

Schlüter, C. 1870a. Neue fossile Echiniden. - Sitzungsberichte der niederrheinischen Gesellschaft für Natur- und Heilkunde zu Bonn 1870: 132-133.

- 1870b. Bericht über eine geognostisch-paläontologische Reise im südlichen Schweden. - Neues Jahrbuch für Mineralogie, Geologie und Paläontologie 1870: 929-969.

- 1899. Ueber einige von Goldfuss beschriebene Spatangiden. II. Stück. - Zeitschrift der deutschen geologischen Gesellschaft 51: 104-124.

- 1900. Ueber einige Kreide-Echiniden. - Zeitschrift der deutschen geologischen Gesellschaft 52: 360-379.

- 1902. Zur Gattung Caratomus (Nebst einigen litterarischen Bemerkungen und Anhang). - Zeitschrift der deutschen geologischen Gesellschaft 54: 302-335.

Schmid, F. 1972. Hagenowia elongata (Nielsen), ein hochspezialisierter Echinide aus dem höheren Untermaastrich NW-Deutschlands. - Geologisches Jahrbuch A4 177-195.

Schulz, M.-G. 1985. Die Evolution der Echiniden-Gattung Galerites im Campan und Maastricht Norddeutschlands. - Geologisches Jahrbuch A80: 3-93.

Schulz, M.-G. \& Weitschat, W. 1998. Part B. The White Chalk (Coniacian-Maastrichtian) of Lägerdorf and Kronsmoor (N-Germany). In Mutterlose, J., Bornemann, A., Rauer, S., Spaeth, C. \& Wood, C. J. (eds). Key localities of the northwest European Cretaceous. - Bochumer geologische und geotechnische Arbeiten 48: 21-37.

Smiser, J. S. 1935. A monograph of the Belgian Cretaceous echinoids. - Mémoires du Musée royal d'Histoire naturelle de Belgique 68: 1-98.

Smith, A. B., Gale, A. S. \& Monks, N. E. A. 2001. Sea level change and rock record bias in the Cretaceous: A problem for extinction and biodiversity studies. Paleobiology 27, 241-253.
Smith, A. B., Gallemí, J., Jeffery, C. H., Ernst, G. \& Ward, P. D. 1999. Late Cretaceous-early Tertiary echinoids from northern Spain: implications for the Cretaceous-Tertiary extinction event. - Bulletin of the Natural History Museum London (Geology) 55: 81-137.

Smith, A. B. \& Jeffery, C. H. 2000. Maastrichtian and Palaeocene echinoids: a key to world faunas. - Special Papers in Palaeontology 63: $1-406$.

Smith, A. B. \& Wright, C. W. 1999. British Cretaceous echinoids. Part 5, Holectypoida, Echinoneoida. - Monograph of the Palaeontographical Society, London 153 (612): $343-390$.

- 2000. British Cretaceous echinoids. Part 6, Neognathostomata (cassiduloids). - Monograph of the Palaeontographical Society, London 154 (615): 391-439.

Stokes, R. B. 1975. Royaumes et provinces fauniques du Crétacé établis sur la base d'une étude systématique du genre Micraster. - Mémoires du Muséum national d'Histoire naturelle n.s. C31: 1-94.

- 1979. The echinoid genus Diplodetus from the Santonian to Danian of Northern Europe. - Neues Jahrbuch für Geologie und Paläontologie, Monatshefte 1979 (10): $619-630$.

Stoliczka, F. 1873. Cretaceous fauna of southern India. The Echinodermata. - Palacontologia Indica (8) 4: 69-129.

Volkmann, R. 1998. Stratigraphie, Fazies und Diagenese des Campan der Lehrter Westmulde bei Höver/Hannover (Niedersachsen). - Berichte der Naturhistorischen Gesellschaft zu Hannover 140: 121-142.

Wahlenberg, G. 1821. Petrificata telluris Suecanae. - Nova Acta Societatis Regiae scientiarum upsaliensis 8 (1818): $1-116$.

Wilmsen, M., Wiese, F. \& Ernst, G. 1996. Facies development, events and sedimentary sequences in the Albian to Maastrichtian of the Santander depositional area, northern Spain. - Mitteilungen aus dem Geologisch-paläontologischen Institut der Universität Hamburg 77: 337-367.

Wiman, C. 1916. Über das Kreidegebiet bei Bastad. - Bulletin Geological Institute, University of Uppsala 15: 77-89.

Wright, C. W. \& Wright, E. V. 1949. The Cretaceous echinoid genera Infulaster Desor and Hagenowia Duncan. Annals and Magazine of Natural History (2) 12: $454-474$.

Zareczny, S. 1878. O rednich warstwach kredewych w krakowskin okr-gu. - Sprawozdanie komis. Fisyograf. Towarstzystwa Nauk Kraków 12: 176-254 [not seen].

Zuidema, G. 1999. Fossiele zee-egels van West-Europa. Gea 32: 73-118.

\section{APPENDIX 1}

Irregular echinoid taxa recorded from the Campanian of the Hannover area (Höver, Misburg and Ahlten) (based on Ernst 1975, Niebuhr et al. 1997 and own observations). Asterisks $\left({ }^{*}\right)$ mark species discussed in the present paper.

\section{Holectypoida}

*Conulus matesovi Poslavskaia \& Moskvin in Moskvin

Galerites (Peroniaster) ernsti Schulz

Galerites roemeri (Desor)

Galerites vulgaris (Leske)

Galerites sulcatoradiatus (Goldfuss)

\section{Cassiduloida}

*Echinogalerus peltiformis (Wahlenberg)

Echinogalerus? hannoniensis (Lambert) 


\section{Holasteroida}

*Hagenowia blackmorei Wright \& Wright Offaster pilula (Lamarck)

Offaster aff. pomeli Munier-Chalmas

Galeola senonensis d'Orbigny

Galeola papillosa papillosa (Leske)

Galeola papillosa basiplana Ernst

Echinocorys gr. conica (Agassiz)

Echinocorys gr. 'gibba/marginata'

Echinocorys subglobosa (Goldfuss)

Echinocorys pyramidata (Portlock)

Cardiotaxis gr. lehmanni/heberti

Cardiaster cordiformis (Woodward)

\section{Spatangoida}

* Hemiaster aquisgranensis Schlüter

*Peroniaster cotteaui Gauthier in Peron

Micraster fastigatus Gauthier, sensu Stokes

(= M. gibbus sensu auct.)

Micraster gr. schroederi/glyphus

Micraster stolleyi Lambert

Diplodetus cretaceus Schlüter

*Diplodetus sp. 